\title{
Post-pandemic consumption: portal to a new world?
}

RUSSELl WilLIAM BeLK ${ }^{1}$

\author{
${ }^{1}$ YORK UNIVERSITY / SCHULICH SCHOOL OF BUSINESS, ONTARIO - CANADA
}

\begin{abstract}
Expert forecasts by consumer researchers and epidemiologists, consumer forecasts, and evidence from China are used to assess how consumer behavior will change after the pandemic subsides. Then hopes for bigger ideas are assessed including really addressing climate change, moving away from fossil fuels, addressing income inequality with a guaranteed income, and decoupling the economy from growth.
\end{abstract}

Keywords: COVID-19. Consumption. Pandemic.

\section{Consumo pós-pandemia: um portal para um mundo novo?}

Resumo

Previsões de especialistas de pesquisadores e epidemiologistas de consumidores, previsões de consumidores e evidências da China são usadas para avaliar como o comportamento do consumidor mudará depois que a pandemia diminuir. Em seguida, esperanças de ideias maiores são avaliadas, incluindo realmente abordar a mudança climática, abandonar os combustíveis fósseis, abordar a desigualdade de renda com uma renda garantida e desvincular a economia do crescimento.

Palavras-chave: COVID-19. Consumo. Pandemia.

\section{Consumo pospandémico: ¿portal a un nuevo mundo?}

\section{Resumen}

Los pronósticos de expertos de investigadores de consumidores y epidemiólogos, los pronósticos de consumidores y la evidencia de China se utilizan para evaluar cómo cambiará el comportamiento de los consumidores después de que la pandemia disminuya. Luego, se evalúan las esperanzas de ideas más grandes, incluido realmente abordar el cambio climático, alejarse de los combustibles fósiles, abordar la desigualdad de ingresos con un ingreso garantizado y desvincular la economía del crecimiento.

Palabras clave: COVID-19. Consumo. Pandemia. 


\section{INTRODUCION}

Historically, pandemics have forced humans to break with the past and imagine their world anew. This one is no different. It is a portal, a gateway between one world and the next (ROY, 2020).

In all likelihood the COVID-19 pandemic is the largest shock to the global status quo we will experience in our lifetimes. It has taken hundreds of thousands of lives, left millions unemployed, and upended the lives of billions of people. Eventually, drugs will emerge to help fight the virus. We will try to resume our lives. But there is also both fear and hope that some things will never be the same.

The effects of the pandemic have not been felt equally by all. Different cultures, races, genders, social classes, occupations, and ages have been affected to different degrees and in different ways. But everyone has been impacted in some way. Those in nursing homes, essential workers, those living alone, children furloughed from school, those unemployed, and those who have lost friends, loved ones, and businesses are among those who have suffered most. Meanwhile, many in professional, back office, or white-collar jobs have been able to shift to working from home and foregoing their commutes. Instead of markets and friends we have turned to social media, online buying, and entertainment services like Netflix. Results include learned agoraphobia, social alienation, and loneliness.

What does this mean for our future work, shopping, savings, and entertainment patterns? What will return and how quickly? What will never resume? And might this once-in-a-lifetime shock to our lives precipitate major changes in lifestyles, income distribution, transportation, and climate action? For answers we can look to expert opinions, examine consumer forecasts, and consider how behavior has changed in places recovering earlier or loosening restrictions first.

\section{Expert Opinions}

While they would be the first to admit that they are guessing, in late April, 2020, I asked a dozen professors and Ph.D. students specializing in consumer research to rate a list of 20 areas of consumption in terms of what changes they expected versus 2019. I told them to assume that there would be no vaccine for at least a year, that cases go down substantially in Summer 2020, that schools, businesses, and governments begin to open by late summer, and that social distancing would still be recommended. They made both short-term and long-term forecasts. I combined their forecasts of whether consumer purchases would be down (a little or a lot), equal to 2019, or up (a little or a lot). Four areas were expected to be up both short-term and long-term: Online buying, Working from home, Saving, and Buying furniture \& home décor. Five consumption areas were expected to be down both short-term and long-term: Foreign travel, Commuting, Movie-going, Arena sports \& concerts, and Car buying. And the remaining 11 areas of consumption were expected to be down in the short-term but up in the long-term: Domestic travel, Luxury buying, Eating out, Going to bars \& clubs, Taking subways \& trams, University education, Haircare, Christmas spending, Going to gym/yoga, Real estate, and Clothes buying. These estimates seem fairly optimistic.

Another group of experts, 511 epidemiologists, were asked in May 2020 to rate a somewhat similar list of consumer activities in terms of when they would resume them: this summer, 3-12 months, 1 year or more, or never again (SANGER-KATZ, MILLER and BUI, 2020). They also offered additional comments about their reasons and qualifications on their responses. Nearly three-fourths of those sampled work in academia, 10 percent in government, and the remainder in nonprofit groups, private companies, and as health care providers.

As might be expected, these epidemiologists were cautious. Only four activities were seen by most as things they would resume this summer: Bring in mail, See a doctor for nonurgent care, Drive to vacation overnight, and Get a haircut. They expected to do half of the activities within 3 to 12 months: Attend a small dinner party, Hike or picnic with friends, Send kids to school, camp, or day care, Work in a shared office, Ride a subway or bus, Visit elderly relative or friend, Travel by plane, Eat in a restaurant, and Exercise at a gym. The remaining six things were seen as requiring a year or longer before they would be resumed: Attend a wedding or funeral, Hug or shake hands, Date someone new, Attend a religious service, Stop wearing a face covering, and Attend a concert, play, or sports event.

There appear to be some larger patterns here. Because working from home was still seen by the first expert group as largely agreeable in late April, it is not surprising that commuting and car buying were predicted to decline and that online buying and spending on home décor were predicted to increase. Moreover, these patterns were expected to be permanent. Given the close proximity to other consumers in some consumption situations, it is also understandable that both groups saw 
air travel, theatergoing, and attendance at arena sports and concerts as either likely to go down or take longer to recover. In general, outdoor activities in small groups were seen to be less risky than indoor and crowded activities. The consumer experts expected activities that involve close proximity to others (public transport, bars and clubs, university education, and gym/yoga) to go down initially but eventually bounce back above 2019 levels. Education may get a boost because in bad job markets, people are more likely to go back to get degrees that will make them more employable (BROWN and HOXBY, 2014; WHISTLE, 2020). Some activities the epidemiologists saw as resuming this summer, like seeing doctors and barbers were seen as more necessary, while others they saw as resuming in 3-12 months, like vacations, restaurant meals, and exercise were seen to be needed for mental health.

Sending kids to school was also seen as a necessity, although the tradeoffs were recognized by these two women (SANGERKATZ, MILLER and BUI, 2020): Ideally I'd wait until a vaccine were available, but the realities of working will probably mean that we will have to send them back when school reopens.

This is a dreaded question. My kids desperately need their friends and a formal learning environment, but I don't necessarily want to send them! But going to concerts, theater, or sports events were seen as dangerous luxuries. One man in the SangerKatz, Miller and Bui (2020) study said he would rather support the arts with his donations. Wearing masks and avoiding shaking hands were seen as temporary necessities, but few people thought they would disappear as soon as a year. They were even seen by one cautious female epidemiologist as necessary in a dating context:

This is tough because dating seems less optional than, say, going to a play or the gym. There are biological clocks to worry about. So I could imagine this being safe now, ONLY IF you could be assured that the person has self-isolated for at least two weeks or more and both of you wore a mask and avoided physical contact, and the meet-up were outdoors.

It remains unclear how this could solve the biological clock problem.

Real estate patterns should also change. Although globalization has meant sending more manufacturing jobs to less expensive parts of the world, the Coronavirus has shown the fragility of supply chains and suggests that we will build more redundant supply chains nearer to major markets (SHARMA, ADHIKARY and BORAH, 2020; ZWANKA and BUFF, 2020). But with telecommuting and Zoom meetings, even while outsourcing production may contract, outsourcing white collar and professional jobs may expand. If so, there is less need for permanent office space in the central city. This space can be converted to apartments, retail, and condominiums (SCHENKER, 2020). Working form home also reduces the necessity to live close to downtown. Millennials and Gen $Z$ consumers who are now renting small expensive apartments downtown may move out to less expensive, more expansive suburbs to raise families, especially given current low mortgage rates. If so, this, plus the new apartment space made available from office downsizing, should make for lower rent prices, attracting lower income people downtown and resulting in more mixed housing patterns (NOVAKOVIC, 2020). All this is speculative, but such a pattern would make sense. It is also supported by projected changes in Airbnb rentals to be discussed later (TENCER, 2020).

\section{Consumer expectations}

After experts, the next source of projections about changes is consumers themselves. In a study of between 1500 and 2200 U.S. adults conducted June 9-11, 2020, the percent who currently felt safe is shown in Figure 1 for each of nine activities (MEYERS, 2020b). It appears that these responses are based on assessed risk of contagion, perceived necessity, and how desirable the activity seems to be as the weather warms and the length of isolation increases. For example, restaurants, vacations, and mall shopping are seen as more attractive than gyms, concerts, and travelling abroad. Being seated in a small space with others is perceived as less safe than being outdoors or in a large space like a mall where people can move around and decide which stores to enter. This pattern generally accords with the expert predictions.

If a BBC (2020a) convenience sample of purchases by high street shoppers after the London lockdown eased is any indication, it looks like there may be a pattern of self-reward. If time in home isolation is a sacrifice or punishment, then initial purchases should be a reward or treat (MILLER, 1998). Shoppers appeared to invoke this logic as they bought handbags, summer clothes, and items of home décor. Consumers confined to homes may also be suffering from the sensory deprivation of not seeing other people outside of their families. The act of going out is a symbolic enactment of freedom, agency, and exerting control over our lives (KIRK and RIFKIN, 2020). It is not a question of anticipated product scarcity like that leading to earlier hoarding of toilet paper and sanitizing supplies (HAMILTON, 2020), but rather a question of the scarcity of face-to-face human interaction and stimulation. 
From a study of 2200 U.S. adults, it appears that most consumers see their consumption activities as eventually returning to prior levels, with some continuing increased activities due to the pandemic (SAKAL, 2020). These increases include playing videogames, spending time on social media, streaming TV, cooking, and buying online. The increase in these activities during the pandemic was mainly among higher income and more educated consumers. Lower income and less educated consumers are more likely to be essential workers or be laid off and to have fewer leisure opportunities and less digital access. The questions of whether consumer behavior will return to pre-pandemic patterns and how soon obviously have serious business and economic implications (SHETH, 2020).

\section{Fast and slow expected recovery: restaurant and travel experiences}

One area of activity that consumers say that they have missed most is going out to restaurants. The top two reasons cited are enjoying the company of others (40\%) and ambiance (19\%) (MEYERS, 2020a). However, dining out is likely to be different and both desires may be difficult to satisfy. Social distancing and group size limits mean that the normal ambient noise and dinner chitchat are constrained. Once-leather-bound menus will become disposable paper menus. And the greeter is likely to be behind a plexiglass screen. Seventeen percent of the 1551 U.S. adults sampled said they missed being served and waited on (MEYERS, 2020a). But waiters and waitresses will wear face coverings and gloves, and customers will likely have to pour their own water and select their own wine. The wait staff will likely not return to ask if everything is OK or if more beverages are desired. It is going to be more difficult to feel special.

At the other end of the post-pandemic recovery envisioned by both the experts and consumers is international air travel. The tourism and hospitality industry relies heavily on such travel. There was a $97 \%$ drop in international tourist arrivals in April (VERSUS, 2019) as airports shut down (UNWTO, 2020). This represents a loss of US\$195 billion in tourist receipts (UNWTO, 2020) and a loss of 1 out of every 10 jobs globally (HE and HARRIS, 2020). Barring a vaccine, there is no quick fix. Domestic tourism and travel within Europe only offer hope for a partial recovery.

Moreover, Airbnb is not doing well; owners of "ghost hotel" units, that comprise 30 percent of Airbnb listings and 80 percent of Airbnb's revenues are being converted into furnished rental apartments (TENCER, 2020). This increased supply should further lessen urban rental prices, but it does not bode well for Airbnb. Hotels have an advantage over Airbnb spaces based on perceived cleaning standards (GLUSAC, 2020). Airbnb has set up a US\$ 250 million fund to help hosts with lost bookings, but only up to $25 \%$ of their losses. Meanwhile Airbnb itself has had to borrow $\$ 2$ billion at 8 to $10 \%$ interest (TENCER, 2020). While more people are now willing to list their properties with Airbnb in order to earn an income, fewer guests are willing to stay. If price elasticity is strong this should drive down prices.

Somewhere in-between the fast restaurant and slow international travel recoveries are small independent retailers (THOMPSON, 2020). Shake-out is predicted with the small and vulnerable succumbing to the loss of business while stronger chains and big box stores survive. Movie theaters will have a hard time due to social distancing and increasing subscriptions to streaming entertainment services. But with careful planning most should be able to survive. Clever adaptations like a return to drive-in movies in empty evening parking lots might be possible.

\section{Recovery in China}

One final line of evidence for consumption after COVID-19 is to learn from the situations of cities and nations that have already reopened, at least temporarily. Both to keep the comparison simple and because China was the first to recover after the initialt outbreak in Wuhan, I will focus on the Chinese case. I use the $12^{\text {th }}$ in a line of weekly "snapshots" by Boston Consulting Group (KOSLOW, LEE, LIU et al., 2020). Based on a May $22^{\text {nd }}-25^{\text {th }}$ sample of 2963 people matched to Chinese demographics, $28 \%$ said the coronavirus had changed their life for the worse (e.g., money pressures, little out of home socializing), $30 \%$ said it had changed their life for the better (e.g., spending time with family, better attention to health, more thoughtful spending), and $46 \%$ said life was very different, but neither good nor bad (e.g., shopping online, frequent hand washing, social distancing).

Post-pandemic Chinese consumers reported that they had traded up in the quality of essentials like food, vitamins, and household care, and traded down in the quality of apparel, restaurant dining, and athletic equipment (KOSLOW, LEE, LIU et al., 2020). Cosmetics, luxury goods, and mobile electronics were more mixed, with some who reported trading up and others who reported trading down. The Chinese are slowly beginning to travel again but long to do more. And increased online buying is a trend that Chinese consumers expected to continue doing more, even among those who had not tried it prior to COVID-19. 


\section{Could COVID-19 precipitate truly big changes?}

On April 30, 2020 I gave a webinar on this topic and the first question I asked the crowd of 450 attendees (electronically) was what they missed most due to COVID-19. As shown in the Word Cloud in Figure 2, one of the striking results was that what we miss most is people! Family, friends, socializing, hugs, human interaction, and people were all in the top ten mentions. It turns out that rather than "Hell is other people" (SARTRE, 1955), quarantine Hell is no other people. The other big cluster of frequently mentioned things had to do with freedom: we miss shopping, travel, walking outside, going out, the outdoors, driving, flexibility, and nature. In other words, what we miss is not so much specific goods or services, but rather human interaction and the ability to freely explore the world outside our front door. This helps put the present focus on consumption in perspective.

I also asked if the webinar audience agreed with two statements. For "In 2021 things will more or less be back to normal," $59 \%$ said yes. But for "Things will never be back to normal" $56 \%$ said yes. There is an obvious contradiction here. It seems more likely that things will never be fully back to pre-pandemic normal. This suggests that some Big Changes may be possible. We might well say "This Changes Everything!" using the more hopeful words of Apple's 2007 iPhone introduction as well as the more fearful title of Naomi Klein's 2014 book on climate change. In the epigraph to the present paper, Roy (2020) reminds us that the pandemic provides a portal between worlds and offers us the opportunity to imagine our world anew. Here I consider just what that new world might be.

\section{Addressing climate change}

The first big idea that many people and especially young people hope may emerge from the pandemic is taking climate change seriously. We have only to look at photos of the cleaner air in Delhi or the skies over major Chinese cities before and after lockdowns to appreciate what a difference being sequestered at home can make to the environment (ZWANKA and BUFF, 2020). We can see vividly how much traffic and factories contribute to air pollution. And the congenial lifestyle changes of working from home and forgoing tension-filled commutes may make seriously tackling climate change an easy sell. Many have found that they can live without unnecessary travelling, for both pleasure and business (STUCKI, 2020).

There could well be a continued lesser use of the automobile and the airplane. This could happen both due to more working from home and curtailing business meetings and conferences that we have learned can be handled online. But arguing against this green optimism is the fact that even with the dramatic decreases in driving, flying, and manufacturing, which contribute approximately a quarter of global carbon emissions, 2020 may still only see a drop of $0.3 \%$ in total global emissions (HENRIQUES, 2020). Also arguing against getting people out of cars and into mass transit is the perception that riding in a tram, bus, or subway car is putting yourself in an enclosed tank full of germs. Short of walking or bicycling, driving a private automobile seems the safest alternative from an epidemiological perspective.

\section{Tackling income inequality}

A second big idea involves income redistribution. The cash supplements paid to individuals during COVID-19 in most advanced economies are very similar to a universal basic income, which is an idea that no longer seems far-fetched. One benefit of a universal basic income is reducing income inequality. In a white paper Philip Kotler (2020) said, in part:

Capitalism remains the best engine for efficient economic growth. It also can be the best engine for equitable economic growth. It doesn't change to socialism when we raise taxes on the rich. We have given up on the false economic doctrine that the poor will win when the rich get richer. Actually, the rich will get richer by leaving more money in the hands of working class families to spend. [...] It's time to rethink and rewire Capitalism and transform it into a more equitable form - based on democracy and social justice. Either we will learn to share more like Scandinavian countries, or we will become a banana republic. We are all in this together.

He points out that people like Bill Gates and Warren Buffet advocate substantial increases in taxes on the rich in order to facilitate this. Better income equality is both a local and a global goal.

A bolder idea than simply redistributing income is to decouple from the idea of perpetual economic growth. As Sigala (2020, p. 314) proposes in the context of tourism: 
At a macro-level, COVID-19 tourism research should generate dethinking, rethinking, and unthinking of pre-assumptions and mindsets including [...] globalisation as an unstoppable force, neoliberal capitalism as the best system and decision-making tool for organizing and allocating resources; growth as the sole way for development and success.

Other prominent tourism researchers have also called for a rethinking of growth as the force behind trying to plan for tourism in a post-pandemic world (GRETZEL, FUCHS, BAGGIO et al., 2020). Sweden, for example, even before COVID-19, started a program called Flygskam, or "flight shaming." Inspired in part by climate change campaigner Greta Thurnberg, the program led to a 4\% decline in the number of people flying from Swedish airports and a 9\% drop in domestic travel in 2019 (BBC, 2020b). Such changes are a small beginning, but the current unplanned reduction in travel adds to the impetus for rethinking the ideology that income growth is needed for a sound economy.

\section{Switch from fossil fuels}

A third possible big change is to dramatically reduce our dependence on fossil fuels by a change to electric vehicles and clean energy sources, again facilitated by more work from home and less commuting. Lessened demand for gasoline should make the switch away from fossil fuels easier as even "oil companies" turn to green energy. The decline in the need for road repair could also allow diversion of funds to better mass transit, bike lanes, and electric vehicle charging stations (VINCE, 2020). It takes great political will to fight the oil lobby and the current low prices for fuel provides less of a consumer incentive to go electric. But with sufficient will it is possible. It also contributes to the "Green New Deal."

A Green New Deal could create new jobs to make up for those lost to COVID-19 and as oil becomes less important. As CNN analysist Zachary Wolf (2020) put it, “Green New Deal fits perfectly on a bumper sticker. But it isn't a simple fix for what ails us. It would equal taking American society back to the drawing board and rebuilding it from the safety net up" - certainly a big change. The seven-point Green New Deal plan passed by the US House of Representatives in 2019 (but rejected by the Senate) is focused on moving the US away from fossil fuels by 2030. Like the original New Deal of the 1930s that helped lift the country out of the Great Depression, the Green New Deal isn't so much a specific set of programs as an umbrella under which various policies can fit (ARONOFF, 2018). It is intended not only to cut carbon emissions and reliance of fossil fuels, but also, like the original New Deal, to fight unemployment, poverty, housing insecurity, and energy inefficiency through green remodeling and jobs in supporting industries.

\section{A negative big idea: ubiquitous surveillance}

As Kirk and Rifkin (2020) note, one of the ways that the spread of COVID-19 has been slowed in Australia and Singapore is through the use of contact tracing via smartphones. This is a voluntary program in Australia, but it gained widespread adoption there with $25 \%$ of the population opting in during its initial week. China also used its phone and CCTV camera surveillance system (part of its Social Credit system - BELK, ECKHARDT and BARDHI, 2019) to follow contagious patients in Wuhan and elsewhere. In the US, Apple and Google jointly created a similar phone tracing algorithm to be used in tracing and back-tracing COVID-19 patients without their having a chance to opt in or out. The idea is that when two people are in close proximity their smartphones do a "Bluetooth handshake." If one of them should later become COVID-19 positive it sends a signal to the other that they may have been exposed and should seek testing (KELION, 2020).

Although the intent of these programs is good, as Sigala (2020) notes, such ubiquitous surveillance is a cause for concern after the pandemic. It can become a part of Big Brother "surveillance capitalism" (ZUBOV, 2015). The privacy we give away in crises like this one and the earlier case of 9-11 are rarely given back.

\section{CONCLUSION}

If there has ever been a moment for undertaking such big ideas, it is now. The aftermath of the Great Depression brought US Social Security, Unemployment Insurance, and massive infrastructure projects. The end of WWII brought the IMF, World Bank, and WTO. Perhaps the current crisis will even prompt the US to adopt universal health care. More importantly, rich nations can help poor nations improve their primary health-care systems. As Mair (2020) observed, "One of the things the COVID-19 crisis could be doing, is expanding our economic imagination." 
As Winston Churchill said while working to form the United Nations after World War II, "Never let a good crisis go to waste." The hope is that something truly momentous can come out of the otherwise horrific COVID-19 crisis. Through the serendipitous discovery of working from home, the collapse of global supply chains, the dramatic reduction in global pollution, and greater recognition of the glaring gap between the rich and the poor, we may have a chance to halt climate change, reduce pollution, lower income inequality, and improve health care for all. Time will tell, but there is hope that this dark cloud has a silver lining.

Figure 1

Percent Who Felt Comfortable 06/15/20

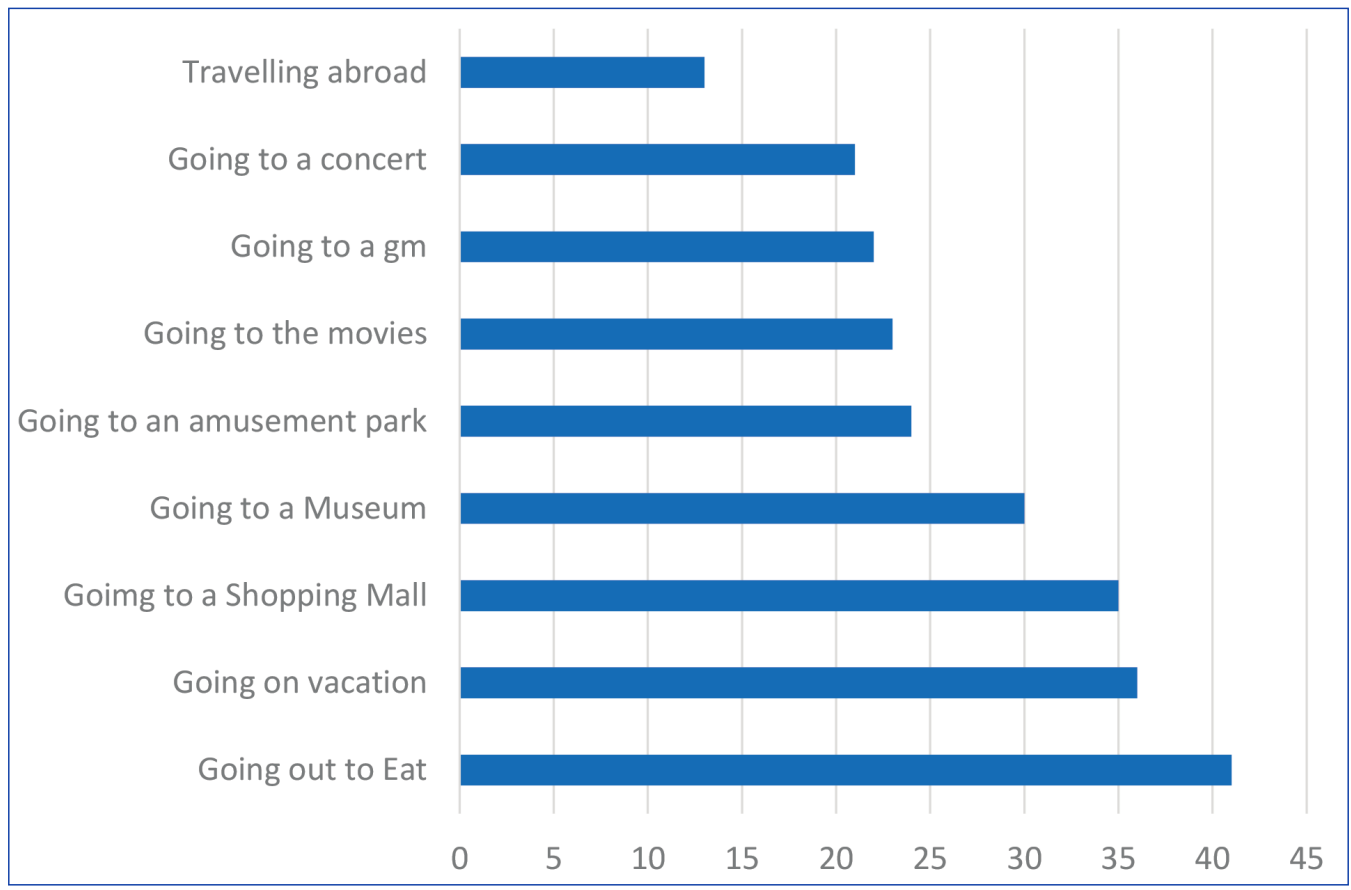

Source: Based on Meyers (2020b).

Figure 2

What do you miss the most due to COVID-19?

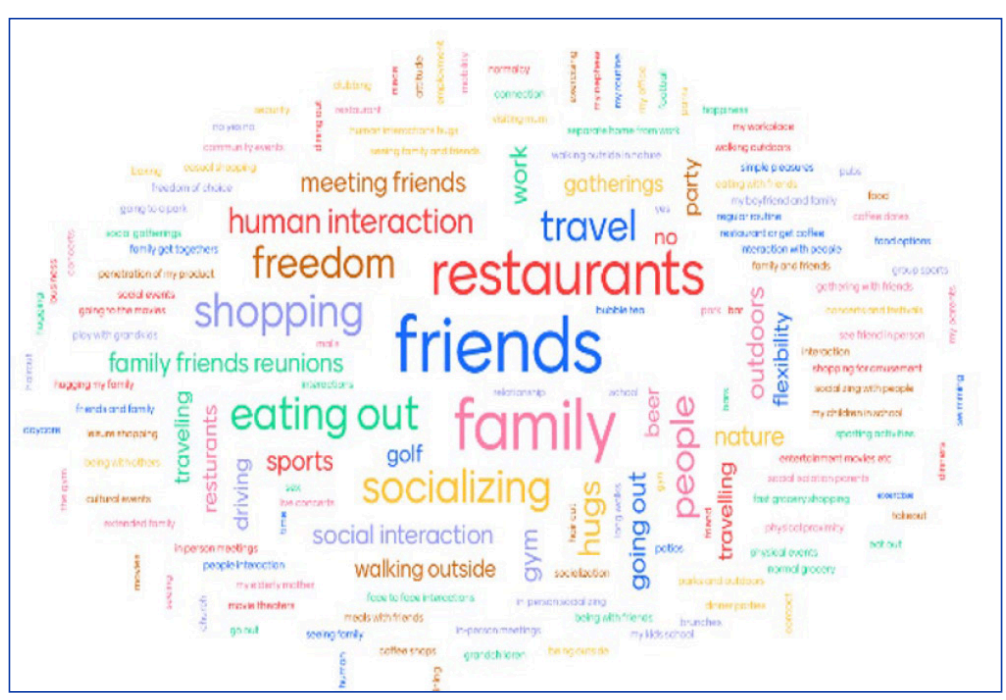

Source: Elaborated by the author. 


\section{REFERENCES}

ARONOFF, K. With a Green New Deal, Here's What the World Could Look Like for the Next Generation. The Intercept, New York, December 05, 2018. Available at: <https://theintercept.com/2018/12/05/greennew-deal-proposal-impacts/>. Accessed on: August 11, 2020.

BBC. Coronavirus: The First Thing I Bought When the Shops Reopened. BBC News, London, June 15, 2020a. Available at: <https://www.bbc.com/news/in-pictures-53055687>. Accessed on: August 11, 2020.

BBC. Sweden sees Rare drop in Air Passengers as Flight-Shaming Takes Off. BBC News, London, January 10, 2020b. Available at: <https://www.bbc.com/news/world-europe-51067440>. Accessed on: August 11, 2020.

BELK, R. W.; ECKHARDT, G. M.; BARDHI, F. Introduction. In: BELK, R. W.; ECKHARDT, G. M.; BARDHI, F. (Eds.). Handbook of the Sharing Economy. Cheltenham: Edward Elgar, 2019. p. 1-8.

BROWN, J.; HOXBY, C. (Eds.). How the Financial Crisis and Great Recession Affected Higher Education. Chicago: University of Chicago Press, 2014.

GLUSAC, E. Hotels, Airbnbs battle an unwelcome disruption. Toronto Star, Toronto, June 04, 2020.

GRETZEL, U. et al. e-Tourism Beyond COVID-19: A Call for Transformative Research. Journal of Information Technology and Tourism, v. 22, n. 2, p. 187-203, 2020.

HAMILTON, R. Scarcity and Coronavirus. Journal of Public Policy and Marketing, May 28, 2020. p. 1-2. Available at: <https://journals. sagepub.com/doi/full/10.1177/0743915620928110>. Accessed on: August 11, 2020.

HE, H.; HARRIS, L. The Impact of Covid-19 Pandemic on Corporate Social Responsibility and Marketing Philosophy. Journal of Business Research, v. 116, p. 176-182, Aug. 2020.

HENRIQUES, M. Will Covid-19 have a Lasting Impact on the Environment?" BBC News, London, March 27, 2020. Available at: <https://www.bbc.com/future/article/20200326-covid-19the-impact-of-coronavirus-on-the-environment>. Accessed on: August 11, 2020.

KELION, L. Coronavirus: First Google/Apple-based Contact-Tracing App Launched. BBC News, London, May 26, 2020. Available at: <https://www.bbc.com/news/technology-52807635>. Accessed on: August 11, 2020.

KIRK, C.; RIFKIN, L. I'Il Trade You Diamonds for Toilet Paper: Consumer Reacting, Coping and Adapting Behaviors in the COVID-19 Pandemic. Journal of Business Research, v. 17, p. 124-131, Sept. 2020.

KOSLOW, L. et al. COVID-19 Consumer Sentiment Snapshot \#12: The Pace Car. Boston Consulting Group, Boston, June 08, 2020. Available at: <https://www.bcg.com/en-ca/publications/2020/covidconsumer-sentiment-survey-snapshot-6-08-20.aspx>. Accessed on: August 11, 2020.

KOTLER, P. The Consumer in the Age of Coronavirus. The Sarasota Institute, April 06, 2020. Available at: <https://sarasotainstitute. global/the-consumer-in-the-age-of-coronavirus/>. Accessed on: August 11, 2020.
MAIR, S. What will the World be like After Coronavirus? Four Possible Futures. The Conversation, Guildford, March 30, 2020. Available at: <https://theconversation.com/what-will-the-world-be-like-aftercoronavirus-four-possible-futures-134085>. Accessed on: August $11,2020$.

MEYERS, A. Diners Miss Community, Ambiance - Two Things that will Likely be Absent as Restaurants Reopen. Morning Consult, Washington, June 11, 2020a. Available at: <https://morningconsult. com/2020/06/11/restaurants-dining-out-ambiance-service-polling/>. Accessed on: August 11, 2020.

MEYERS, A. When Will Consumers Feel Safe Again? Morning Consult, Washington, June 15, 2020b. Available at: <https://morningconsult. com/2020/06/15/tracking-consumer-comfort-with-dining-out-andother-leisure-activities/>. Accessed on: August 11, 2020.

MILLER, D. A Theory of Shopping. Ithaca: Cornell University Press, 1998.

NOVAKOVIC, S. Will COVID-19 Spell the End of Urban Density? Don't Bet on It. Azure Magazine, Toronto, May 29, 2020. Available at: $<$ https://www.azuremagazine.com/article/will-covid-19-spell-theend-of-urban-density-dont-bet-on-it/>. Accessed on: August 11, 2020.

ROY, A. The Pandemic is a Portal. Financial Times, London, April 03, 2020. Available at: <https://www.ft.com/content/10d8f5e8-74eb11ea-95fe-fcd274e920ca>. Accessed on: August 11, 2020.

SAKAL, V. Analysis: How Our Favorite Pastimes Will Change in a Post COVID-19 World. Morning Consult, Washington, April 28, 2020. Available at: <https://morningconsult.com/2020/04/28/favoritepastimes-covid/>. Accessed on: August 11, 2020.

SANGER-KATZ, M.; MILLER, C.; BUI, Q. When 511 Epidemiologists Expect to Fly, Hug and Do 19 Other Everyday Activities Again. New York Times, New York, June 08, 2020. Available at: <https://www.nytimes. com/interactive/2020/06/08/upshot/when-epidemiologists-will-doeveryday-things-coronavirus.html>. Accessed on: August 11, 2020.

SARTRE, J. P. No Exit, and Three Other Plays. New York: Vintage Books, 1955.

SCHENKER, J. The Future After COVID: Futurist Expectations for Changes, Challenges, and Opportunities After the COVID-19 Pandemic. Austin: Prestige Professional Publishing, 2020.

SHARMA, A.; ADHIKARY, A.; BORAH, S. Covid-19's Impact on Supply Chain Decisions: Strategic Insights for NASDAQ 100 Firms using Twitter Data. Journal of Business Research, v. 117, p. 443-449, Sept. 2020. Available at: <https://doi.org/10.1016/j.jbusres.2020.05.035>. Accessed on: August 11, 2020.

SHETH, J. Impact of Covid-19 on Consumer Behavior: Will the Old Habits return or Die? Journal of Business Research, v. 117, p. 280283, Sept. 2020.

SIGALA, M. Tourism and COVID-19: Impacts and Implications for Advancing Resetting Industry and Research. Journal of Business Research, v. 117, p. 312-321, Sept. 2020.

STUCKI, M. Covid-19 -- The World After: What will the world after coronavirus look like? Different, but Still the Same. Future Proof, Helsinki, March 20, 2020. Available at: <https://www.futuresplatform. com/blog/covid-19-world-after>. Accessed on: August 11, 2020. 
TENCER, D. Airbnb's Flameout in the COVID-19 Pandemic Could be Good News for Renters and Homebuyers. Huffington Post, Québec, April 18, 2020. Available at: <https://www.huffingtonpost.ca/entry/ airbnb-canada-housing_ca_5e9a1538c5b635d25d6c6aa8>. Accessed on: August 11, 2020.

THOMPSON, D. Pandemic Will Change American Retail Forever. The Atlantic, Washington, April 27, 2020. Available at: <https://www. theatlantic.com/ideas/archive/2020/04/how-pandemic-will-changeface-retail/610738/>. Accessed on: August 11, 2020.

VINCE, G. After the COVID-19 Crisis, Will We get a Greener World? The Guardian, London, May 17, 2020. Available at: <https://www. theguardian.com/environment/2020/may/17/after-the-covid-19crisis-will-we-get-a-greener-world>. Accessed on: August 11, 2020.

WHISTLE, W. What a Likely Recession Means for Higher Education? Forbes, New York, April 06, 2020. Available at: <https://www.forbes. com/sites/wesleywhistle/2020/04/06/what-a-likely-recession-meansfor-higher-education/\#59f511766f83>. Accessed on: August 11, 2020.

WOLF, Z. Here's What the Green New Deal Actually Says. CNN News, Atlanta, March 02, 2020. Available at: <https://www.cnn. com/2019/02/14/politics/green-new-deal-proposal-breakdown/ index.html>. Accessed on: August 11, 2020.

WORLD TOURISM ORGANIZATION - UNWTO. UNWTO World Tourism Barometer. Madrid: UNWTO, June 2020.

ZUBOFF, S. The Age of Surveillance Capitalism: The Fight for a Human Future at the New Frontier of Power. New York: Public Affairs, 2019.

ZWANKA, R. J.; BUFF, C. COVID-19 Generation: A Conceptual Framework of Consumer Behavioral Shifts to be Caused by the COVID-19 Pandemic. Journal of International Consumer Marketing, May 29, 2020. Available at: <https://www.tandfonline.com/doi/full/10.1080/08961530.202 0.1771646>. Accessed on: August 11, 2020. 